\title{
The Innate Immune System in Transplantation
}

\author{
Martin H. Oberbarnscheidt ${ }^{\mathrm{a}}$, Daniel Zecher ${ }^{\mathrm{b}}$, and Fadi G. Lakkis ${ }^{\mathrm{a}}$ \\ Martin H. Oberbarnscheidt: oberbarnscheidtmh@upmc.edu; Daniel Zecher: daniel.zecher@unibas.ch
}

aThomas E. Starzl Transplantation Institute, Departments of Surgery, Immunology, and Medicine, University of Pittsburgh, Pittsburgh, PA, 15261, USA bepartment of Transplantation Immunology and Nephrology, University Hospital Basel, $\mathrm{CH}-4031$ Basel, Switzerland

\section{Abstract}

The vertebrate innate immune system consists of inflammatory cells and soluble mediators that comprise the first line of defense against microbial infection and, importantly, trigger antigenspecific $\mathrm{T}$ and $\mathrm{B}$ cell responses that lead to lasting immunity. The molecular mechanisms responsible for microbial non-self recognition by the innate immune system have been elucidated for a large number of pathogens. How the innate immune system recognizes non-microbial nonself, such as organ transplants, is less clear. In this review, we approach this question by describing the principal mechanisms of non-self, or 'damaged' self, recognition by the innate immune system (pattern recognition receptors, the missing self theory, and the danger hypothesis) and discussing whether and how these mechanisms apply to allograft rejection.

\section{Keywords}

Innate immune system; Innate immunity; Transplantation; Rejection; Allorecognition; Monocyte

\section{Introduction}

The mammalian immune system consists of two integrated arms, the innate and adaptive, whose principal function is to defend the host against infection (1-3). The adaptive immune system consists of $\mathrm{T}$ and $\mathrm{B}$ lymphocytes which express diverse and highly specific antigen receptors brought about by somatic gene rearrangement, expand clonally, and generate immunological memory. Unlike the adaptive system, the innate immune system comprises inflammatory cells (dendritic cells, monocytes, macrophages, neutrophils, and other cells) that do not express rearranging receptors, have limited clonal expansion, and, in the most part, do not generate memory. Cells of the innate immune system instead express germ-line encoded pattern recognition receptors (PRR) that detect conserved pathogen associated molecular patterns (PAMP) present in microbes but not shared by mammalian cells $(4,5)$. The innate immune system also encompasses non-cellular mediators capable of microbial recognition - for example, complement proteins. Activation of the innate immune system by

(C) 2011 Elsevier Ltd. All rights reserved.

Address Correspondence to: Fadi G. Lakkis, M.D., University of Pittsburgh, Thomas E. Starzl Transplantation Institute, W1548 Thomas E. Starzl Biomedical Science Tower 200 Lothrop Street, Pittsburgh, PA 15261, Phone: 412-383-5774 Fax: 412-383-9990, lakkisf@upmc.edu.

Publisher's Disclaimer: This is a PDF file of an unedited manuscript that has been accepted for publication. As a service to our customers we are providing this early version of the manuscript. The manuscript will undergo copyediting, typesetting, and review of the resulting proof before it is published in its final citable form. Please note that during the production process errors may be discovered which could affect the content, and all legal disclaimers that apply to the journal pertain. 
microbial ligands causes inflammation, the first line of defense against infection, but more importantly induces the maturation and migration of antigen-presenting cells (APC) to secondary lymphoid tissues where they trigger primary $\mathrm{T}$ cell and B cell responses. The latter function of the innate immune system is critical for initiating adaptive immunity to infection and vaccines in the naïve host. The innate immune system is therefore responsible for the first self-non-self recognition events that ultimately lead to productive $\mathrm{T}$ and $\mathrm{B}$ cell immunity.

This conceptual framework of immunity was proposed in 1989 by Charles Janeway, Jr. (6). He posited at the time that immunological recognition extends beyond clonally distributed receptors on T and B cells, which are prone to self-reactivity, to germline-encoded PRR that are selected over evolutionary time and therefore distinguish microbial non-self from self with high fidelity. Importantly, he predicted that sensing infection by PRR would also confer on innate APC the ability to deliver second signals that are required for T lymphocyte activation. These predictions have been borne out by the discovery of several families of PRR that detect specific classes of microbial products and trigger both inflammation and the maturation of APC that initiate adaptive immunity. Therefore, the innate immune system as we know it now is not only a first-line defense system synonymous with non-recognitive inflammation but one that distinguishes between self and non-self and shapes the adaptive immune response. It is within this conceptual framework that the role of innate immunity in transplantation will be discussed here.

\section{The problem with transplantation}

Allograft rejection is a powerful adaptive immune response characterized by substantial $\mathrm{T}$ and B cell activation and the generation of long-lasting immunological memory. Up to $10 \%$ of the $\mathrm{T}$ cell repertoire participates in the alloimmune response in mice and humans $(7,8)$, leading to considerable lymphocyte proliferation, differentiation, and cytokine production. Whereas it is established that in the adaptive immune system $\mathrm{T}$ cells are necessary and sufficient for transplant rejection (9-11), the innate pathways responsible for triggering alloimmunity have defied definition so far. Alloimmunity appears to be initiated largely, or perhaps entirely, independent of innate signaling pathways known to be essential for antimicrobial immunity (discussed below). The same can be said for graft-versus-host disease (GVHD) after hematopoietic stem cell or bone marrow transplantation (12). In this review, we will take 'a step back' and ask whether the major concepts of innate immune activation gleaned largely from work outside the transplantation arena apply or do not apply to the initiation of alloimmunity. These concepts include non-self sensing by PRR, the missing-self theory, the danger theory, and the guard theory (13). We will also briefly discuss in this review the role of specific innate immune cells (e.g., neutrophils and monocytes) that could link innate to adaptive immunity in transplantation. Due to space limitations, important areas of innate immunity such as its regulation by the adaptive immune system as well as many innate cytokines that influence the immune response will not be addressed (14).

\section{Non-self sensing by PRR}

Recognition of PAMP by PRR forms the cornerstone of the Janeway theory and provides a robust explanation for how the adaptive immune response to a large variety of pathogens is initiated by the innate immune system (4). PRR that have been discovered so far fall into two main categories, trans-membrane and cytosolic, and account for microbial non-self sensing in locations outside and within the cell. A third category consists of secreted pattern recognition molecules that bind to microbial cell surfaces and activate complement or opsonize pathogens for phagocytosis. 


\subsection{Trans-membrane PRR}

Transmembrane PRR detect the presence of pathogens in the extracellular space or in phagosomes and endosomes. The canonical trans-membrane PRR is the toll-like receptor (TLR) family whose individual members recognize microbial cell wall components and microbial nucleic acids (reviewed in $(5,15)$ ). Examples include the recognition of lipopolysaccharide (LPS) of Gram-negative bacteria (TLR4) $(16,17)$, lipoteichoic acid of Gram-positive bacteria (TL1/TLR2), bacterial lipoproteins (TLR2/TLR6), flagellin (TLR5), double-stranded RNA (TLR3), single-stranded RNA (TLR7), and double-stranded DNA (TLR9). TLR activation stimulates the classical events required for initiating and regulating the adaptive immune response: antigen uptake and presentation, dendritic cell maturation and migration, control of naïve $\mathrm{T}$ cell activation through costimulation and cytokines (leading predominantly to a Th1 response), control of T cell survival, control of effector $\mathrm{T}$ cells by regulatory $\mathrm{T}$ cells, and shaping $\mathrm{T}$ cell-dependent and independent $\mathrm{B}$ cell responses (3). Another trans-membrane PRR is Dectin-1, a member of the C-type lectin family, which recognizes $\beta$-glucans unique to fungal pathogens (18). Dectin- 1 triggering results in an adaptive immune response dominated by Th17 cells (19).

Alloimmunity, like anti-microbial immunity, is a T cell-dependent process where both Th1 and Th17 cells participate, with the former dominating in most rejection models (20). What then is the role of trans-membrane PRR if any in initiating allograft rejection? Goldstein et al provided the first evidence that signaling via TLR may be critical for allograft rejection (21). They demonstrated that skin grafts transplanted between mice mismatched for the male (HY) minor antigen are not rejected if both donor and recipient lacked Myd88. Myd88 is an intracellular adaptor molecule essential for signaling via TLR except for TLR3, which uses the adaptor molecule TRIF (22). Myd88 deficiency in these experiments was associated with reduced accumulation of mature dendritic cells and $\mathrm{HY}$-specific $\mathrm{CD} 8^{+} \mathrm{T}$ cells in the recipients' draining lymph nodes. TLR2 or TLR4 deficiency alone or Myd88 deficiency restricted to either donor or host was not sufficient to prevent rejection. The initial excitement that alloimmunity may utilize the same pattern recognition pathways that evolved for the purpose of microbial sensing was quickly tempered by the finding that allograft rejection proceeded largely unabated in the absence of Myd88 or both Myd88 and TRIF if donor and recipient mismatch extended beyond a single minor antigen $(23,24)-$ which is the case in all of clinical transplantation except for transplants performed between identical twins. That innate recognition via TLR is not necessary for alloimmunity held true for skin (24), vascularized (heart) (23), and cell (pancreatic islet) allografts (25), as well as GVHD (12). In humans, correlations between TLR4 polymorphisms and the incidence of kidney and lung rejection have been reported $(26,27)$. These observations could support a direct role for TLR in human alloimmunity but, alternatively, may be a reflection of the indirect effects of anti-microbial immune responses, which are regulated by TLR, on the alloimmune response.

Although TLR pathways are not critical for allograft rejection, there is ample evidence that they contribute to the pathogenesis of ischemia-reperfusion injury - a form of injury to which all grafts are subjected during the transplantation procedure. The extent to which ischemia-reperfusion injury mediated by PRR or other components of the innate immune system influence the adaptive alloimmune response will be discussed later in this review. There is also increasing experimental evidence that signaling via TLR prevents or abrogates transplantation tolerance and, conversely, the absence of TLR signaling facilitates tolerance (28-31). These effects are likely mediated by TLR expressed on myeloid cells, lymphoid cells, or both. It is not clear whether these findings imply a central role for TLR in alloimmunity or simply illustrate how host-microbe interactions can interfere with tolerance (for example, via type I IFN, IL-6, or TNFa production) $(32,33)$. The contribution of the commensal flora (microbiota) to the host's innate immune response against non-microbial 
antigens is increasingly being recognized $(34,35)$. Conspicuous autoimmune or tumor phenotypes often observed in mice that lack critical innate pathways (for example, colitis in NLRP6-deficient mice) have been found to be the indirect consequence of changes in the animal's intestinal flora rather than a direct role of a given innate pathway in disease pathogenesis (36).

\subsection{Cytosolic PRR}

Cytosolic PRR detect PAMP present in the cytosol. They include the retinoic acid inducible gene I (RIG-I)-like helicases (RLH), the nucleotide-binding oligomerization domain (NOD)like receptors (NLR), and the presumed interferon (IFN)-stimulatory DNA (ISD) sensor (4). RLH members RIG-I and melanoma differentiation factor 5 (MDA5) detect viral RNA and trigger the signaling cascade that leads to type 1 IFN production (37). The NLR family members NOD1 and NOD2 recognize peptidoglycan fragments from bacterial cell walls, while NALP proteins (e.g., NALP3) are crucial for the formation of large cytosolic complexes known as inflammasomes that control the activation of caspase- 1 and the secretion of the caspase-1-dependent cytokines IL-1 and IL-18 (38). Although some inflammasomes may directly recognize PAMP, it appears that their most conspicuous function (at least in the case of the NALP3 inflammasome) is to initiate inflammation in response to various forms of cellular stress such as breach in membrane integrity, rapid efflux of potassium caused by high extracellular ATP concentration, presence of uric acid crystals, and possibly metabolic stress caused by hyperglycemia (39). Finally, the ISD sensor (which remains to be identified) may contribute to type 1 IFN production after DNA vaccination or infection with DNA viruses and retroviruses $(40,41)$. RLH and the ISD sensor therefore participate in initiating and shaping anti-microbial adaptive immune responses through type 1 IFN production while the NALP3 inflammasome could do so through IL-1 and IL-18 secretion. The adjuvant alum, widely used in human vaccines, activates the NALP3 inflammasome and is dependent on IL-1 $\beta$ for its effects on the adaptive immune system (42).

Experimental evidence available so far does not support a critical role for cytosolic PRR activation in allograft rejection. Mice that lack the IFN-1 receptor (IFN-1R) mount normal primary and secondary alloimmune responses, reject skin allografts acutely, and develop GVHD at the same rate and severity as wildtype mice $(12,43)$. Although cogent arguments have been made that IL-1 could potentiate alloimmunity (44), in vivo evidence that IL-1 is critical for allograft rejection is lacking as illustrated by the normal tempo of rejection and of GVHD in caspase 1- and Myd88-deficient mice (12, 21, 23). However, blocking TIR8, a regulator of signaling by the IL-1 receptor family (which include the IL-1, IL-18, and IL-33 receptors) (45), accelerates renal allograft rejection in mice (46), suggesting that universal blockade of the IL-1 receptor family may be needed before significant delay in acute rejection is observed. Finally, it remains to be tested whether IL-1 blockade prevents or ameliorates chronic allograft rejection, and experiments in which the role of RIG, NOD, or NALP in allograft rejection is investigated directly have not been reported yet.

\subsection{Secreted PRR and the complement system}

The pentraxins, collectins, and ficolins are families of soluble (humoral) pattern recognition molecules that sense microbial surfaces [reviewed in (47)]. A well-studied member of the pentraxin family is C-reactive protein (CRP), an acute phase reactant in humans, which resembles an antibody and binds to phosphocholine on microbes. The collectin family consists of C-type lectins (proteins that bind sugar moieties), the most prominent example being mannose- or mannan-binding lectin (MBL). MBL recognizes carbohydrate patterns on bacteria, fungi, viruses, and protozoa. The ficolins share structural and functional properties with the collectins. In addition to sensing microbes, secreted PRR bind to apoptotic and 
necrotic mammalian cells and are therefore implicated in non-microbial inflammation (47). Secreted PRR have in common the ability to trigger phagocytosis through opsonization of their targets, and, importantly, they initiate inflammation and shape the adaptive immune response by activating the complement system via either the classical (CRP) or lectin (MBL and ficolins) pathways (47). The alternative pathway of complement activation on the other hand is triggered by hydrolyzed $\mathrm{C} 3$ or by properdin, a globular serum protein with features of PRR that recognizes microbes and apoptotic cells. C3 spontaneously activated by hydrolysis is thought to keep the complement system in an 'alert' mode, while complement regulators - for example, decay accelerating factor (DAF) present on host cells but not on microbes - protect the host against self attack (48).

The complement system has gained significant attention lately as a modulator of the adaptive alloimmune response. Work by Sacks, Heeger, and Medof has provided strong evidence that complement produced by the graft tissue or by immune cells not only amplifies inflammation and antibody-dependent cytotoxicity but also potentiates $\mathrm{T}$ cell activation $(49,50)$. The finding by Sacks and colleagues that wildtype mice with normal serum complement do not reject C3-deficient kidney allografts instigated this paradigm shift (51). Subsequent studies showed that C3-deficient heart allografts survive longer than their wildtype counterparts (median survival time $=25$ vs 17 days, respectively) but, unlike C3deficient kidneys, $80 \%$ of heart allografts were rejected by day 50 (52). It was later established that locally produced complement molecules (C3a and C5a) activate APC to produce cytokines (e.g., IL-12 and IL-23) and upregulate costimulatory molecules $(53,54)$. In addition, complement produced by T cells and APC during cognate T cell-APC interactions directly augments the adaptive response by binding to $\mathrm{C} 3 \mathrm{a}$ and $\mathrm{C} 5 \mathrm{a}$ receptors on $\mathrm{T}$ cells and preventing their apoptosis (55). Complement activation in these settings occurs through the alternative pathway as a consequence of decay-accelerating factor (DAF) downregulation (56). The relevance of the alternative pathway to transplantation is supported by the finding that donor DAF deficiency accelerates T cell-mediated allograft rejection (52). One could therefore envision the complement system as an innate response system that modulates the adaptive alloimmune response by enhancing $T$ cell costimulation. Although clearly important, this system may not be critical because multiple redundant pathways of $\mathrm{T}$ cell costimulation exist.

\section{The missing-self theory}

The missing-self theory was first proposed 25 years ago to account for the lysis of tumor cells or virus-infected cells by natural killer (NK) cells $(57,58)$. NK cells express both inhibitory and activating receptors (59-61). The former engage self-MHC class I molecules with high specificity while the latter recognize ligands induced by cellular stress. Whether NK cells lyse their target or not is determined by the balance between inhibitory and activating signals. Transformed or virus-infected cells that lack self-MHC class I ("missing self") cannot inhibit NK cells and are killed, while healthy host cells that express MHC class I ("self") are spared. In addition to lysing their targets, activated NK cells shape the adaptive immune response by producing cytokines (e.g., IFN $\gamma$ ) that impact APC, T cells, and B cells (61). Although initially thought of as innate cells because they lack rearranging antigen receptors, recent data suggest that NK cells (which in fact share the same lymphoid progenitor as $\mathrm{T}$ and $\mathrm{B}$ cells) possess adaptive features such as memory (61).

Based on the missing-self theory, allografts from donors mismatched with recipients at MHC class I loci cannot deliver inhibitory signals to recipient NK cells and are therefore expected to activate them $(62,63)$. What then is the role of NK cells in rejection? Experiments in inbred mice have clearly demonstrated that NK cells are necessary and sufficient for the rejection of bone marrow transplants between parental donors and F1 
recipients (64). In this setting, recipient $\mathrm{T}$ and $\mathrm{B}$ cells are tolerant to parental antigens and rejection of the bone marrow is mediated by NK cells instead - a phenomenon referred to as "hybrid resistance" (65). Similarly, mice that lack T cells reject MHC class I-mismatched bone marrow allografts through NK-mediated killing, albeit less vigorously than rejection mediated by $\mathrm{T}$ cells (66). In contrast, NK cells are neither necessary nor sufficient for the acute rejection of solid organ allografts (67), although exceptions have been reported under specific experimental circumstances. These include cardiac allograft rejection in CD28 ${ }^{-/-}$ recipients (68-70), skin allograft rejection in lymphocyte-deficient mice whose NK cell population were dramatically boosted by exogenous IL-15 (71), and chronic allograft vasculopathy in lymphocyte-deficient recipients reconstituted with CD4 T cells $(72,73)$. Under other experimental conditions NK cells have been shown to downregulate the host's adaptive alloimmune response by killing donor dendritic cells (74), presumably killing activated $\mathrm{T}$ cells $(75,76)$, or by inhibiting the homeostatic proliferation of CD8 T cells in lymphopenic recipients (77). NK depletion in wildtype mice, however, does not affect the tempo of acute allograft rejection significantly even in recipients that are also $\mathrm{T}$ cell depleted (67). Conversely, mice that lack T cells but have intact NK cells accept solid organ allografts indefinitely and, similarly, F1 or MHC class I-deficient ( $\beta 2$-microglobulin gene knockout) skin allografts are not rejected despite eliciting strong NK responses $(78,79)$. Therefore, missing-self recognition by NK cells contributes to allograft rejection and to the regulation of the alloimmune response but does not appear to be a critical link between the innate and adaptive systems in the transplant setting.

The discovery over the past decade or more of several inhibitory immunoglobulin superfamily (IgSF) receptors restricted mainly to myeloid cells has extended the concept of missing-self recognition beyond NK cells in mice and humans (80). Phagocytosis is negatively regulated by inhibitory receptors that include SIRPa and members of the Siglec, CD200R, CD300, SLAM, and other paired immunoglobulin-like receptor (PIR) families (81-85). Some but not all of these receptors contain immunoreceptor tyrosine-based inhibitory motifs (ITIM) in their cytosolic domains. SIRPa binds to CD47 expressed ubiquitously on self-cells and delivers a "do not eat me" signal to macrophages. If CD47 expression is absent or low (for example, on senescent RBCs or tumor cells) $(86,87)$, or if the target cells express a distinct CD47 allele (for example, xenografts)(88), then phagocytosis occurs more efficiently. In an analogous fashion, Siglecs bind specifically to host but not microbial sialic acids or the sialic acids of an animal species distinct from the host, therefore allowing phagocytosis of pathogens or xenogeneic cells while preventing damage to self tissues (82). CD200R1 on myeloid cells binds ubiquitously expressed CD200 and, similar to SIRPa, suppresses macrophage function (89). Inhibitory receptors also regulate the differentiation and maturation of APC. SIRPa inhibits phenotypic and functional maturation of DC but its effects on adaptive immune responses are complicated by the fact that it also promotes $\mathrm{T}$ cell activation, presumably by interacting with $\mathrm{CD} 47$ on $\mathrm{T}$ cells $(90,91)$. Thus, SIRPa- or CD47-deficient mice are resistant, rather than hypersusceptible, to classical T cell-mediated responses such as contact hypersensitivity (92), and experimental autoimmune encephalomyelitis (93). CD200-deficient mice, on the other hand, harbor APC with an activated phenotype (at least in the skin) and exhibit increased susceptibility to experimentally-induced models of autoimmunity or infection $(83,89$, 94-96). It should be noted that myeloid and NK inhibitory receptors are often paired with stimulatory receptors (80). These paired membrane proteins are encoded by different genes located within the same gene cluster on a given chromosome, are expressed on overlapping immune cell populations, and share significant amino acid and structural homologies in their extracellular domains but differ in their intracellular domains, delivering either activating or inhibitory signals to the cell (for example, SIRPa and CD200R1 are paired with the activating receptors SIRP- $\beta 1$ and CD200R2-4, respectively). Such pairing is consistent with the current view that "missing self recognition is essentially a negative control of some 
activating signal and thus always works in conjunction with an activating pathway". Therefore, the outcome of missing self recognition, whether by NK cells or myeloid cells, is determined by the balance between activating and inhibitory signals.

Although myeloid inhibitory receptors participate in the host's response to xenografts, their role in alloimmunity is less clear. Gorczynski and colleagues investigated the effects of manipulating the CD200-CD200R1 pathway on alloimmune responses and graft rejection. They found that an agonistic CD200-Fc fusion protein delays acute skin and renal allograft rejection in rats by a significant but modest degree (97). In mice, CD200-Fc prolonged skin allograft survival from approximately 12 to 20 days, but CD200R1-deficiency in the host did not alter the tempo of rejection (98). Similarly, skin and cardiac allograft survival was not significantly prolonged in CD200-transgenic mice, but half of the recipients accepted the allografts indefinitely if treated with a low dose of rapamycin transiently after transplantation (99). The authors could demonstrate in these experimental models that enhanced engagement of CD200R1 by CD200 suppressed allosensitization in vitro and in vivo(100). SIRPa, on the other hand, has been shown to modulate engraftment of xeno(human) and allogeneic hematopoietic stem cell grafts in mice. SIRPa polymorphism accounted for enhanced acceptance of human hematopoietic stem cells by NOD-SCID mice compared to SCID mice on a non-NOD background (101). In this case, NOD SIRPa bound human CD47 with higher affinity than non-NOD SIRPa leading to modulation of host bone marrow macrophage function and increased engraftment of the xenogeneic stem cells. Analogously, CD47 expression on donor lymphohematopoietic cells determined the extent to which they are cleared by recipient macrophages after allogeneic bone marrow transplantation. CD47-deficient marrow failed to reconstitute heavily irradiated or immunedeficient recipients suggesting that inhibition of macrophages or other innate immune cells via the CD47- SIRPa pathway is required for optimal engraftment of allogeneic hematopoietic stem cells (102). The role of this pathway in modulating the innate and adaptive immune response to solid organ allografts has not been reported yet. Finally, mice lacking PIR-B, an inhibitory receptor expressed on B cells and myeloid cells, develop heightened GVHD after the transfer of allogeneic splenocytes that could be attributed to augmented activation of recipient DC (103). Suciu-Foca and colleagues have shown in a study of human heart transplant recipients that increased expression of leukocyte immunoglobulin-like receptor (LILR)-B2 and LILR-B4 (LILRs are the human orthologs of mouse PIRs) marks tolerogenic human DC (104), suggesting a role for these inhibitory pathways in preventing the rejection of solid organ allografts.

\section{The Danger Hypothesis}

The danger hypothesis, proposed in 1994 by Polly Matzinger, states that the adaptive immune system did not evolve to respond to microbial non-self per se but to nonphysiological cell death, damage or stress - collectively referred to as 'danger' $(105,106)$. This view was prompted by the need to provide an explanation for robust immune responses that occur in the absence of obvious microbial adjuvants, principally those generated against non-microbial non-self (for example, tissue allografts and tumors) or against self-antigens (autoimmunity). The danger hypothesis is supported by evidence that innate immune cells, in addition to recognizing PAMP, respond to markers of cell stress or death. The latter have been termed danger associated molecular patterns (DAMP) or 'alarmins'. DAMP consist of a wide variety of endogenous molecules released by stressed or dying cells or tissues. They include reactive oxygen species, ATP, monosodium urate crystals, the nuclear high mobility group protein B1 (HMGB1), nuclear DNA, mitochondrial DNA, hyaluronic acid, heparan sulfate, and possibly many others $(44,106)$. 
It is well established that DAMP cause or amplify tissue inflammation and trigger tissue repair in response to dying cells in the setting of sterile inflammation (e.g., ischemiareperfusion injury and transplantation) $(44,107)$, but they can also act as adjuvants that enhance DC maturation and potentiate the adaptive immune response (106). A primary example of an adjuvant DAMP is uric acid (monosodium urate) crystals. Uric acid is present in low concentration (and therefore non-crystalline form) in the extracellular space but is present in crystalline form when it reaches high concentrations, as is the case in gout or under conditions of excessive cell death. Uric acid crystals cause inflammation via NALP3 inflammasome activation and IL-1 production $(108,109)$, and also induce DC maturation in vitro and in vivo(110). Inhibition of uric acid formation by allopurinol or its removal by administering uricase to mice reduced the generation of cytotoxic $\mathrm{T}$ cells against non-self antigen (the HIV antigen gp120 expressed on transplanted syngeneic cells) and the proliferation of autoreactive $\mathrm{T}$ cells in a diabetes model (111). Uric acid removal also delayed the rejection of allogeneic tumors in mice (112). Another adjuvant DAMP is ATP. Like uric acid, it is present in low amounts in the extracellular space but causes inflammation when its concentration increases (113). ATP is rapidly metabolized by ectonucleotidases (CD39 and CD73) present on the surface of many cell types to produce adenosine, which counteracts the inflammatory actions of ATP (114). Both ATP and adenosine modulate the functions of APC and T cells (113). In a GVHD model, Wilhelm et al provided evidence that ATP released by dying cells after host irradiation induces the expression of CD80 and CD86 co-stimulatory molecules on DC in vitro and in vivo, increases inflammatory cytokine production, and potentiates $\mathrm{T}$ cell proliferation (115). ATP neutralization or blockade of the $\mathrm{P} 2 \mathrm{X}_{7} \mathrm{R}$ ATP receptor reduced the severity of GVHD in mice. Numerous studies have demonstrated that conversion of ATP to adenosine is protective in models of ischemia-reperfusion injury and xenotransplantation (116). More recently, Crikis et al demonstrated that transgenic overexpression of CD39 protectes against transplant vasculopathy in a mouse kidney transplantation model (117). Similar to uric acid and ATP, succinate, also released by dying cells, has been shown to act as an adjuvant in vivo and, in the setting of transplantation, potentiates rejection (118). Allografts from donors that lack the succinate receptor GPR91 were rejected more weakly (a modest delay of few days) than those from wild-type mice. Finally, HMGB1, a nuclear protein DAMP that plays a prominent role in ischemia-reperfusion injury of native organs $(107,119)$, also contributes to allograft rejection. Blocking RAGE, a receptor of HMGB1, delayed the acute rejection of mouse cardiac allografts from a mean of 7 to 20 days (120). Other examples of DAMP that participate in ischemia-reperfusion injury, have adjuvant properties, and could potentially enhance rejection have been reviewed elsewhere $(44,106,121)$. In addition, mounting evidence indicates that mitochondria and mitochondrial components contribute to the innate immune response after infection or cell damage $(122,123)$.

Despite the evidence presented above, it remains unclear whether the danger hypothesis fully accounts for innate immune activation after transplantation. First, no single DAMP or group of related DAMP has emerged as necessary and sufficient for allograft rejection. This is best exemplified by the fact that blocking TLR or IL-1 signaling, both of which are common pathways through which most DAMP mediate their effects, has only a modest effect on alloimmunity and allograft survival (discussed previously in this review). The same applies to IL-6, which is significantly upregulated after ischemia-reperfusion injury or transplantation and is known to promote adaptive immunity (124). Second, the fact that TLR4 mediates the action of many seemingly unrelated DAMP (107) begs the question whether 'danger' phenomena observed in some experimental models are mediated by LPS that either contaminates organs at the time of transplantation or enters the circulation from the gut during mouse manipulation (e.g., anesthesia and surgery). Third, the effects of DAMP as triggers of inflammation are difficult to distinguish from their role as adjuvants. Antigen-independent graft inflammation influences the rejection tempo by modulating the 
migration of effector and memory T cells to allografts (125). Although inflammation is without question an important modulator of rejection, it is not in the purest sense a reflection of self-non-self recognition - the central tenet of the Janeway hypothesis of innate immunity. Finally, it is still unclear whether the danger hypothesis can account for persistent recognition of allografts by the adaptive immune system long after the immediate transplantation (ischemia-reperfusion) period $(78,126)$. This question will be revisited at the end of the review.

\section{The Guard Hypothesis}

The guard hypothesis stems from studying plant immunity. In addition to expressing PRR that recognize PAMP, plants also possess microbial resistance genes, the products of which monitor or 'guard' critical cellular pathways that are often targeted by microbial virulence factors (127). Alterations in a cellular pathway caused by infection activate the 'guard' gene product, which in turn triggers a defense response in the plant. Therefore, guard molecules do not directly recognize microbial non-self but instead indirectly respond to their presence by sensing pathophysiological perturbations caused by them. It has been proposed that in animal innate immunity the NALP3 inflammasome could be thought of as a guard molecule that senses perturbations in the cell membrane $(13,128)$. For example, pathogens or nonmicrobial events that breach membrane integrity (e.g., pore forming bacterial toxins) activate the inflammasome through lowering of cytosolic potassium concentration. The guard hypothesis is therefore in many ways an extension of the danger hypothesis whereby the innate system indirectly recognizes and is activated by 'modified self'.

\section{The Role of Innate Immune Cells in Transplantation}

The discussion so far has focused on non-self and modified-self innate sensing pathways and how they relate to transplantation. Here we will briefly address the role of myeloid cells of the innate immune system, other than DC, in the alloimmune response.

\subsection{Neutrophils}

Neutrophils infiltrate allografts within hours after transplantation and are an important source of chemokines and other inflammatory mediators (129). Short-term neutrophil depletion, or restraining granulopoiesis in the bone marrow (130), reduces tissue damage associated with ischemia-reperfusion injury, but alone does not prolong allograft survival to a great degree. Neutrophil depletion or blocking neutrophil migration, however, synergizes with co-stimulation blockade to induce long-term allograft survival $(131,132)$. The latter finding suggests that neutrophils potentiate the adaptive alloimmune response. There are several mechanisms by which neutrophils could do so: by causing tissue inflammation that increases effector and memory $\mathrm{T}$ cell infiltration into the graft, by producing cytokines such as IL-12 that influence T cell priming, or by enhancing antigen presentation (133). Studies in infection models have shown that neutrophils can directly interact with dendritic cells or present antigen to T cells $(134,135)$, but these possibility have not been investigated in transplantation yet.

\subsection{Monocytes}

Monocytes represent a significant proportion of bone marrow, splenic, and blood myeloid cells. They migrate to sites of microbial or non-microbial inflammation rapidly and differentiate into tissue macrophages or DC (136-138). There is increasing evidence that monocyte-derived DC, rather than tissue-resident conventional DC (which derive from a bone marrow precursor known as pre-cDC), play a significant role in presenting antigen after infection (139). Recent data by the Gelman and Kreisel groups have provided direct visual evidence that monocytes infiltrate lung allografts before neutrophils do and that 
neutrophil migration is indeed monocyte-dependent (140). In the setting of lung transplantation, monocyte migration is CCR2-dependent and leads to the accumulation of DC in the graft (141). This finding challenges the dogma that neutrophils are the earliest sentinels to arrive at sites of inflammation. We have found that host monocytes infiltrate heart allografts within the first 20 hours after transplantation and rapidly differentiate into mature DC (Oberbarnscheidt \& Lakkis, unpublished data). In fact, the vast majority of DC present in the allograft by three days after transplantation is derived from host monocytes, and increased numbers of monocyte-derived DC could be found in the regional lymph nodes as well. Therefore, in addition to generating effector cells like macrophages, monocytes serve as immediate precursors of DC at sites of inflammation where non-self antigens are present. Monocytes, therefore, could link innate and adaptive immunity after transplantation.

An additional and intriguing feature of monocytes that make them likely candidates for initiating or sustaining the alloimmune response is their capacity to distinguish between self and allogeneic non-self, a phenomenon that we have referred to as 'innate allorecognition'. Zecher et al demonstrated in a cutaneous delayed-type hypersensitivity (DTH) mouse model that $\mathrm{RAG}^{--}$mice mount an alloimmune response to allogeneic splenocytes (142). Maximal response required prior priming with alloantigen, exhibited crude specificity (donor-specific recall response $>3^{\text {rd }}$ party response), occurred independent of NK cells, and targeted allodeterminants unlinked to the MHC. Alloresponsiveness could be conferred to naïve $\mathrm{RAG}^{-/-}$mice by sorting and transferring pure monocyte populations from allosensitized $\mathrm{RAG}^{-/-}$mice, strongly indicating a central role for monocytes in innate allorecognition. These findings echo prior hints in the literature that the mouse innate immune system responds to allogeneic non-self and that monocytes could have a role in human kidney allograft rejection in profoundly $\mathrm{T}$ cell depleted recipients (143-145).

Finally, monocytes can also differentiate into cells with suppressive functions. Studies in tumor immunity have suggested the presence of tumor-infiltrating $\mathrm{Gr}^{+}$myeloid cell populations with immunosuppressive functions - commonly referred to as myeloid-derived suppressor cells (MDSC) (146). Although the exact nature of MDSC remains to be defined (they appear to include monocyte-, macrophage-, and neutrophil-like cells), there is mounting evidence that MDSC contribute to transplantation tolerance. Ochando and colleagues have shown that depleting $\mathrm{CD}_{1} 1 \mathrm{~b}^{+}$cells abrogates tolerance induced by donorspecific transfusion and anti-CD40L treatment in mice (147). Moreover, Bronte and colleagues provided evidence that the transfer of bone marrow-derived MDSC prolongs murine islet allograft survival when co-transferred with $\mathrm{T}$ cells to lymphocyte-deficient recipients (148).

\subsection{Eosinophils and Mast Cells}

Transplant pathologists have long identified eosinophils among the cells infiltrating allografts during acute rejection and have anecdotally associated them with severe rejection of kidney, liver, and heart transplants. Recently, Wu et al described eosinophil-rich infiltrates in human small bowel allograft biopsies from lymphocyte-depleted patients (149), suggesting a potential role of eosinophils in the innate response. In mouse models, eosinophils promote allograft rejection when classical Th1 pathways are blocked $(150,151)$. Although mast cells, like eosinophils, are established mediators of allergic responses, they also modulate non-allergic adaptive immune responses (152). Mast cells contribute to the initiation and severity of experimental allergic encephalomyelitis in mice (153), but in the setting of transplantation have been shown to be essential for tolerance that is dependent on regulatory T cells (154). The latter function is mediated by IL-9, a mast cell growth and activation factor. Additional studies are needed to further define the roles of eosinophils and mast cells, as well as other less-studied myeloid cells such as the newly described nuocytes (155), in the innate alloimmune response. 


\subsection{Basophils}

It has been shown that basophils, rather than dendritic cells, function as the APC that initiates Th2 responses to allergens and possibly parasites $(156,157)$, although this intriguing possibility has been challenged by others (158). Adaptive Th2 immunity figures prominently in transplantation, but the role of basophils in the innate immune response to transplanted organs, if any, is not known.

\section{Conclusion: An alternate view of innate alloimmunity?}

Although the innate recognition pathways required for establishing anti-microbial immunity have been uncovered for many infectious diseases, how the innate immune system triggers the adaptive alloimmune response is not as straightforward. Many innate sensing pathways that figure prominently in anti-microbial immunity appear to be neither sufficient nor necessary for alloimmunity. Moreover, myriad inflammatory mediators that influence both the afferent and efferent (effector) arms of the alloimmune response are released at the time of transplantation due to ischemia-reperfusion injury of the transplanted organ. These early events can obscure non-self recognition events akin to those that occur after microbial infection and at the same time do not explain how alloimmunity can still be triggered long after ischemia-reperfusion injury has resolved. Is there then a glimmer of an orderly paradigm in this seemingly chaotic setting?

We wish to propose here that the rules of innate recognition in transplantation differ from those that apply to microbial infection and, therefore, require alternate approaches to uncover them. First, the Janeway paradigm has been very successful at explaining how naïve $\mathrm{T}$ cell responses are initiated but did not as much take into consideration recall responses that are less dependent on co-stimulation. The $\mathrm{T}$ cell response to allogeneic tissues is in large part a memory response even in naïve individuals (8). Therefore, it may or may not depend on classical innate recognition pathways required for DC activation. The question in transplantation then becomes one of how memory T cells are recalled? Are professional APC necessary? Is inflammation ('danger') required for memory T cells to enter the sites where foreign antigen resides? In other words, how much or what type of innate activation is required for eliciting a productive memory response? Second, the study of immunology has been largely microbe-centric because of the assumption that immune systems have evolved to protect animals, and plants for that matter, against infection. Therefore, alloimmunity is perceived as an unintended effect of anti-microbial immunity. This argument, although clearly valid, excludes the possibility that allorecognition mechanisms may have evolved independently to protect individuals against situations where parasitism by non-self, nonmicrobial cells could be harmful (159). These include stem cell parasitism and the transmission of tumor cells between individuals (160-163). Examples of evolutionary ancient allorecognition systems that predate adaptive immunity are prevalent in nature (164-167). Therefore, is it possible that innate allorecognition mechanisms exist in mammals despite the evolution of a highly successful adaptive immune system? Can these mechanisms account for persistent recognition of transplanted organs, or persistence of 'danger' in allografts, long after ischemia-reperfusion injury phase has subsided? Answering these questions could shed fundamental insights into the pathogenesis of both acute and chronic rejection.

\section{Acknowledgments}

This work was funded by NIH grant AI064343 to FGL. MO was funded by the Thomas E. Starzl Fellowship in Transplantation Biology (University of Pittsburgh). DZ was funded by a grant from the Deutsche Forschungsgemeinschaft. 


\section{References}

1. Janeway CJ. How the immune system works to protect the host from infection. Proc Natl Acad Sci U S A. 2001; 98:7461-7468. [PubMed: 11390983]

2. Medzhitov R. Recognition of microorganisms and activation of the immune response. Nature. 2007; 449:819-826. [PubMed: 17943118]

3. Iwasaki A, Medzhitov R. Regulation of adaptive immunity by the innate immune system. Science. 2010; 327:291-295. [PubMed: 20075244]

4. Palm NW, Medzhitov R. Pattern recognition receptors and control of adaptive immunity. Immunol Rev. 2009; 227:221-233. [PubMed: 19120487]

5. Beutler BA. TLRs and innate immunity. Blood. 2009; 113:1399-1407. [PubMed: 18757776]

6. Janeway CA Jr. Approaching the asymptote? Evolution and revolution in immunology. Cold Spring Harb Symp Quant Biol. 1989; 54 Pt 1:1-13. [PubMed: 2700931]

7. Suchin EJ, Langmuir PB, Palmer E, Sayegh MH, Wells AD, Turka LA. Quantifying the frequency of alloreactive T cells in vivo: new answers to an old question. J Immunol. 2001; 166:973-981. [PubMed: 11145675]

8. Macedo C, Orkis EA, Popescu I, Elinoff BD, Zeevi A, Shapiro R, Lakkis FG, Metes D. Contribution of naive and memory T-cell populations to the human alloimmune response. Am J Transplant. 2009; 9:2057-2066. [PubMed: 19624567]

9. Miller JFAP. Effect of neonatal thymectomy on the immunological responsiveness of the mouse. Proc R Soc Lond B. 1962; 156:415-428.

10. Hall BM, Dorsch S, Roser B. The cellular basis of allograft rejection in vivo. I. The cellular requirements for first-set rejection of heart grafts. J Exp Med. 1978; 148:878-889. [PubMed: 359750]

11. Hall BM. Cells mediating allograft rejection. Transplantation. 1991; 51:1141-1151. [PubMed: 1675502]

12. Li H, Matte-Martone C, Tan HS, Venkatesan S, McNiff J, Demetris AJ, Jain D, Lakkis F, Rothstein D, Shlomchik WD. Graft-versus-host disease is independent of innate signaling pathways triggered by pathogens in host hematopoietic cells. J Immunol. 2011; 186:230-241. [PubMed: 21098219]

13. Medzhitov R. Approaching the asymptote: 20 years later. Immunity. 2009; 30:766-775. [PubMed: 19538928]

14. Zhao J, Yang X, Auh SL, Kim KD, Tang H, Fu YX. Do adaptive immune cells suppress or activate innate immunity? Trends Immunol. 2009; 30:8-12. [PubMed: 19058755]

15. Akira S, Takeda K. Toll-like receptor signalling. Nature Rev Immunol. 2004; 4:499-511. [PubMed: 15229469]

16. Poltorak A, He X, Smirnova I, Liu MY, Van Huffel C, Du X, Birdwell D, Alejos E, Silva M, Galanos C, Freudenberg M, Ricciardi-Castagnoli P, Layton B, Beutler B. Defective LPS signaling in C3H/HeJ and C57BL/10ScCr mice: mutations in Tlr4 gene. Science. 1998; 282:2085-2088. [PubMed: 9851930]

17. Medzhitov R, PrestonHurlburt P, Janeway CA. A human homologue of the Drosophila Toll protein signals activation of adaptive immunity. Nature. 1997; 388:394-397. [PubMed: 9237759]

18. Brown GD, Gordon S. Immune recognition. A new receptor for beta-glucans. Nature. 2001; 413:36-37. [PubMed: 11544516]

19. LeibundGut-Landmann S, Gross O, Robinson MJ, Osorio F, Slack EC, Tsoni SV, Schweighoffer E, Tybulewicz V, Brown GD, Ruland J, Reis e Sousa C. Syk- and CARD9-dependent coupling of innate immunity to the induction of T helper cells that produce interleukin 17. Nat Immunol. 2007; 8:630-638. [PubMed: 17450144]

20. Atalar K, Afzali B, Lord G, Lombardi G. Relative roles of Th1 and Th17 effector cells in allograft rejection. Curr Opin Organ Transplant. 2009; 14:23-29. [PubMed: 19337142]

21. Goldstein DR, Tesar BM, Akira S, Lakkis FG. Critical role of the Toll-like receptor signal adaptor protein MyD88 in acute allograft rejection. J Clin Invest. 2003; 111:1571-1578. [PubMed: 12750407] 
22. Hoebe K, Du X, Georgel P, Janssen E, Tabeta K, Kim SO, Goode J, Lin P, Mann N, Mudd S, Crozat K, Sovath S, Han J, Beutler B. Identification of Lps2 as a key transducer of MyD88independent TIR signalling. Nature. 2003; 424:743-748. [PubMed: 12872135]

23. Tesar BM, Zhang J, Li Q, Goldstein DR. TH1 immune responses to fully MHC mismatched allografts are diminished in the absence of MyD88, a toll-like receptor signal adaptor protein. Am J Transplant. 2004; 4:1429-1439. [PubMed: 15307830]

24. McKay D, Shigeoka A, Rubinstein M, Surh C, Sprent J. Simultaneous deletion of MyD88 and Trif delays major histocompatibility and minor antigen mismatch allograft rejection. Eur J Immunol. 2006; 36:1994-2002. [PubMed: 16874736]

25. Hutton MJ, Westwell-Roper C, Soukhatcheva G, Plesner A, Dutz JP, Verchere CB. Islet allograft rejection is independent of toll-like receptor signaling in mice. Transplantation. 2009; 88:10751080. [PubMed: 19898202]

26. Palmer SM, Burch LH, Davis RD, Herczyk WF, Howell DN, Reinsmoen NL, Schwartz DA. The role of innate immunity in acute allograft rejection after lung transplantation. Am J Respir Crit Care Med. 2003; 168:628-632. [PubMed: 12773319]

27. Palmer SM, Burch LH, Trindade AJ, Davis RD, Herczyk WF, Reinsmoen NL, Schwartz DA. Innate immunity influences long-term outcomes after human lung transplant. Am J Respir Crit Care Med. 2005; 171:780-785. [PubMed: 15640363]

28. Chen L, Wang T, Zhou P, Ma L, Yin D, Shen J, Molinero L, Nozaki T, Phillips T, Uematsu S, Akira S, Wang CR, Fairchild RL, Alegre ML, Chong A. TLR engagement prevents transplantation tolerance. Am J Transplant. 2006; 6:2282-2291. [PubMed: 16970798]

29. Kim JI, Lee MKt, Moore DJ, Sonawane SB, Duff PE, O'Connor MR, Yeh H, Lian MM, Deng S, Caton AJ, Markmann JF. Regulatory T-cell counter-regulation by innate immunity is a barrier to transplantation tolerance. Am J Transplant. 2009; 9:2736-2744. [PubMed: 19845585]

30. Porrett PM, Yuan X, LaRosa DF, Walsh PT, Yang J, Gao W, Li P, Zhang J, Ansari JM, Hancock WW, Sayegh MH, Koulmanda M, Strom TB, Turka LA. Mechanisms underlying blockade of allograft acceptance by TLR ligands. J Immunol. 2008; 181:1692-1699. [PubMed: 18641305]

31. Walker WE, Nasr IW, Camirand G, Tesar BM, Booth CJ, Goldstein DR. Absence of innate MyD88 signaling promotes inducible allograft acceptance. J Immunol. 2006; 177:5307-5316. [PubMed: 17015716]

32. Wang T, Chen L, Ahmed E, Ma L, Yin D, Zhou P, Shen J, Xu H, Wang CR, Alegre ML, Chong AS. Prevention of allograft tolerance by bacterial infection with Listeria monocytogenes. J Immunol. 2008; 180:5991-5999. [PubMed: 18424719]

33. Ahmed EB, Wang T, Daniels M, Alegre ML, Chong AS. IL-6 Induced by Staphylococcus aureus Infection Prevents the Induction of Skin Allograft Acceptance in Mice. Am J Transplant. 2011; 11:936-946. [PubMed: 21449942]

34. Medzhitov R. Innate immunity: quo vadis? Nat Immunol. 2010; 11:551-553. [PubMed: 20562835]

35. Macdonald TT, Monteleone G. Immunity, inflammation, and allergy in the gut. Science. 2005; 307:1920-1925. [PubMed: 15790845]

36. Elinav E, Strowig T, Kau AL, Henao-Mejia J, Thaiss CA, Booth CJ, Peaper DR, Bertin J, Eisenbarth SC, Gordon JI, Flavell RA. NLRP6 Inflammasome Regulates Colonic Microbial Ecology and Risk for Colitis. Cell. 2011

37. Takeuchi O, Akira S. MDA5/RIG-I and virus recognition. Curr Opin Immunol. 2008; 20:17-22. [PubMed: 18272355]

38. Davis BK, Wen H, Ting JP. The inflammasome NLRs in immunity, inflammation, and associated diseases. Annu Rev Immunol. 2011; 29:707-735. [PubMed: 21219188]

39. Schroder K, Zhou R, Tschopp J. The NLRP3 inflammasome: a sensor for metabolic danger? Science. 327:296-300. [PubMed: 20075245]

40. Stetson DB, Medzhitov R. Recognition of cytosolic DNA activates an IRF3-dependent innate immune response. Immunity. 2006; 24:93-103. [PubMed: 16413926]

41. Ishii KJ, Akira S. Innate immune recognition of, and regulation by, DNA. Trends Immunol. 2006; 27:525-532. [PubMed: 16979939] 
42. Eisenbarth SC, Colegio OR, O'Connor W, Sutterwala FS, Flavell RA. Crucial role for the Nalp3 inflammasome in the immunostimulatory properties of aluminium adjuvants. Nature. 2008; 453:1122-1126. [PubMed: 18496530]

43. Oberbarnscheidt MH, Obhrai JS, Williams AL, Rothstein DM, Shlomchik WD, Chalasani G, Lakkis FG. Type I interferons are not critical for skin allograft rejection or the generation of donor-specific CD8+ memory T cells. Am J Transplant. 2010; 10:162-167. [PubMed: 19951284]

44. Rao DA, Pober JS. Endothelial injury, alarmins, and allograft rejection. Crit Rev Immunol. 2008; 28:229-248. [PubMed: 19024347]

45. Garlanda C, Anders HJ, Mantovani A. TIR8/SIGIRR: an IL-1R/TLR family member with regulatory functions in inflammation and T cell polarization. Trends Immunol. 2009; 30:439-446. [PubMed: 19699681]

46. Noris M, Cassis P, Azzollini N, Cavinato R, Cugini D, Casiraghi F, Aiello S, Solini S, Cassis L, Mister M, Todeschini M, Abbate M, Benigni A, Trionfini P, Tomasoni S, Mele C, Garlanda C, Polentarutti N, Mantovani A, Remuzzi G. The Toll-IL-1R member Tir8/SIGIRR negatively regulates adaptive immunity against kidney grafts. J Immunol. 2009; 183:4249-4260. [PubMed: 19734209]

47. Bottazzi B, Doni A, Garlanda C, Mantovani A. An integrated view of humoral innate immunity: pentraxins as a paradigm. Annu Rev Immunol. 2010; 28:157-183. [PubMed: 19968561]

48. Ricklin D, Hajishengallis G, Yang K, Lambris JD. Complement: a key system for immune surveillance and homeostasis. Nat Immunol. 2010; 11:785-797. [PubMed: 20720586]

49. Zhou W, Medof ME, Heeger PS, Sacks S. Graft-derived complement as a mediator of transplant injury. Curr Opin Immunol. 2007; 19:569-576. [PubMed: 17764920]

50. Vieyra MB, Heeger PS. Novel aspects of complement in kidney injury. Kidney Int. 2010; 77:495499. [PubMed: 20016462]

51. Pratt JR, Basheer SA, Sacks SH. Local synthesis of complement component C3 regulates acute renal transplant rejection. Nat Med. 2002; 8:582-587. [PubMed: 12042808]

52. Pavlov V, Raedler H, Yuan S, Leisman S, Kwan WH, Lalli PN, Medof ME, Heeger PS. Donor deficiency of decay-accelerating factor accelerates murine $\mathrm{T}$ cell-mediated cardiac allograft rejection. J Immunol. 2008; 181:4580-4589. [PubMed: 18802060]

53. Lalli PN, Strainic MG, Lin F, Medof ME, Heeger PS. Decay accelerating factor can control T cell differentiation into IFN-gamma-producing effector cells via regulating local C5a-induced IL-12 production. J Immunol. 2007; 179:5793-5802. [PubMed: 17947652]

54. Strainic MG, Liu J, Huang D, An F, Lalli PN, Muqim N, Shapiro VS, Dubyak GR, Heeger PS, Medof ME. Locally produced complement fragments C5a and C3a provide both costimulatory and survival signals to naive CD4+ T cells. Immunity. 2008; 28:425-435. [PubMed: 18328742]

55. Lalli PN, Strainic MG, Yang M, Lin F, Medof ME, Heeger PS. Locally produced C5a binds to T cell-expressed C5aR to enhance effector T-cell expansion by limiting antigen-induced apoptosis. Blood. 2008; 112:1759-1766. [PubMed: 18567839]

56. Heeger PS, Lalli PN, Lin F, Valujskikh A, Liu J, Muqim N, Xu Y, Medof ME. Decay-accelerating factor modulates induction of T cell immunity. J Exp Med. 2005; 201:1523-1530. [PubMed: 15883171]

57. Karre K, Ljunggren HG, Piontek G, Kiessling R. Selective rejection of H-2-deficient lymphoma variants suggests alternative immune defence strategy. Nature. 1986; 319:675-678. [PubMed: 3951539]

58. Karre K. How to recognize a foreign submarine. Immunol Rev. 1997; 155:5-9. [PubMed: 9059878]

59. Lanier L. NK cell recognition. Annu Rev Immunol. 2005; 23:225-274. [PubMed: 15771571]

60. Lanier LL. Up on the tightrope: natural killer cell activation and inhibition. Nat Immunol. 2008; 9:495-502. [PubMed: 18425106]

61. Vivier E, Raulet DH, Moretta A, Caligiuri MA, Zitvogel L, Lanier LL, Yokoyama WM, Ugolini S. Innate or adaptive immunity? The example of natural killer cells. Science. 2011; 331:44-49.

[PubMed: 21212348] 
62. Ohlen C, Kling G, Hoglund P, Hansson M, Scangos G, Bieberich C, Jay G, Karre K. Prevention of allogeneic bone marrow graft rejection by H-2 transgene in donor mice. Science. 1989 ; 246:666668. [PubMed: 2814488]

63. Bix M, Liao NS, Zijlstra M, Loring J, Jaenisch R, Raulet D. Rejection of class I MHC-deficient haemopoietic cells by irradiated MHC-matched mice. Nature. 1991; 349:329-331. [PubMed: 1987491]

64. Yankelevich B, Knobloch C, Nowicki M, Dennert G. A novel cell type responsible for marrow graft rejection in mice. T cells with NK phenotype cause acute rejection of marrow grafts. $\mathrm{J}$ Immunol. 1989; 142:3423-3430. [PubMed: 2654290]

65. Cudkowicz G, Stimpfling JH. Induction of Immunity and of Unresponsiveness to Parental Marrow Grafts in Adult F-1 Hybrid Mice. Nature. 1964; 204:450-453. [PubMed: 14232531]

66. Murphy WJ, Kumar V, Bennett M. Acute rejection of murine bone marrow allografts by natural killer cells and T cells. Differences in kinetics and target antigens recognized. J Exp Med. 1987; 166:1499-1509. [PubMed: 3316472]

67. Heidecke CD, Araujo JL, Kupiec-Weglinski JW, Abbud-Filho M, Araneda D, Stadler J, Siewert J, Strom TB, Tilney NL. Lack of evidence for an active role for natural killer cells in acute rejection of organ allografts. Transplantation. 1985; 40:441-444. [PubMed: 3901444]

68. Maier S, Tertilt C, Chambron N, Gerauer K, Huser N, Heidecke CD, Pfeffer K. Inhibition of natural killer cells results in acceptance of cardiac allografts in CD28-/- mice. Nat Med. 2001; 7:557-562. [PubMed: 11329056]

69. McNerney ME, Lee KM, Zhou P, Molinero L, Mashayekhi M, Guzior D, Sattar H, Kuppireddi S, Wang CR, Kumar V, Alegre ML. Role of natural killer cell subsets in cardiac allograft rejection. Am J Transplant. 2006; 6:505-513. [PubMed: 16468959]

70. Kim J, Chang CK, Hayden T, Liu FC, Benjamin J, Hamerman JA, Lanier LL, Kang SM. The activating immunoreceptor NKG2D and its ligands are involved in allograft transplant rejection. J Immunol. 2007; 179:6416-6420. [PubMed: 17982029]

71. Kroemer A, Xiao X, Degauque N, Edtinger K, Wei H, Demirci G, Li XC. The innate NK cells, allograft rejection, and a key role for IL-15. J Immunol. 2008; 180:7818-7826. [PubMed: 18523245]

72. Uehara S, Chase CM, Kitchens WH, Rose HS, Colvin RB, Russell PS, Madsen JC. NK cells can trigger allograft vasculopathy: the role of hybrid resistance in solid organ allografts. J Immunol. 2005; 175:3424-3430. [PubMed: 16116237]

73. Kitchens WH, Uehara S, Chase CM, Colvin RB, Russell PS, Madsen JC. The changing role of natural killer cells in solid organ rejection and tolerance. Transplantation. 2006; 81:811-817. [PubMed: 16570001]

74. Yu G, Xu X, Vu MD, Kilpatrick ED, Li XC. NK cells promote transplant tolerance by killing donor antigen-presenting cells. J Exp Med. 2006; 203:1851-1858. [PubMed: 16864660]

75. Beilke JN, Kuhl NR, Van Kaer L, Gill RG. NK cells promote islet allograft tolerance via a perforin-dependent mechanism. Nat Med. 2005; 11:1059-1065. [PubMed: 16155578]

76. Bose A, Inoue Y, Kokko KE, Lakkis FG. Cutting edge: perforin down-regulates CD4 and CD8 T cell-mediated immune responses to a transplanted organ. J Immunol. 2003; 170:1611-1614. [PubMed: 12574320]

77. Zecher D, Li Q, Oberbarnscheidt MH, Demetris AJ, Shlomchik WD, Rothstein DM, Lakkis FG. NK cells delay allograft rejection in lymphopenic hosts by downregulating the homeostatic proliferation of CD8+ T cells. J Immunol. 2010; 184:6649-6657. [PubMed: 20483732]

78. Bingaman AW, Ha J, Waitze SY, Durham MM, Cho HR, Tucker-Burden C, Hendrix R, Cowan SR, Pearson TC, Larsen CP. Vigorous allograft rejection in the absence of danger. J Immunol. 2000; 164:3065-3071. [PubMed: 10706695]

79. Zijlstra M, Auchincloss H, Loring JM, Chase CM, Russell PS, Jaenisch R. Skin graft rejection by beta 2-microglobulin-deficient mice. J Exp Med. 1992; 175:885-893. [PubMed: 1552287]

80. Yamada E, McVicar DW. Paired receptor systems of the innate immune system. Curr Protoc Immunol. 2008; Chapter 1:Appendix 1X. [PubMed: 18491293]

81. Matozaki T, Murata Y, Okazawa H, Ohnishi H. Functions and molecular mechanisms of the CD47-SIRPalpha signalling pathway. Trends Cell Biol. 2009; 19:72-80. [PubMed: 19144521] 
82. Crocker PR, Paulson JC, Varki A. Siglecs and their roles in the immune system. Nat Rev Immunol. 2007; 7:255-266. [PubMed: 17380156]

83. Barclay AN, Wright GJ, Brooke G, Brown MH. CD200 and membrane protein interactions in the control of myeloid cells. Trends Immunol. 2002; 23:285-290. [PubMed: 12072366]

84. Clark GJ, Ju X, Tate C, Hart DN. The CD300 family of molecules are evolutionarily significant regulators of leukocyte functions. Trends Immunol. 2009; 30:209-217. [PubMed: 19359216]

85. Cannons JL, Tangye SG, Schwartzberg PL. SLAM family receptors and SAP adaptors in immunity. Annu Rev Immunol. 29:665-705. [PubMed: 21219180]

86. Oldenborg PA, Zheleznyak A, Fang YF, Lagenaur CF, Gresham HD, Lindberg FP. Role of CD47 as a marker of self on red blood cells. Science. 2000; 288:2051-2054. [PubMed: 10856220]

87. Jaiswal S, Chao MP, Majeti R, Weissman IL. Macrophages as mediators of tumor immunosurveillance. Trends Immunol. 31:212-219. [PubMed: 20452821]

88. Ide K, Wang H, Tahara H, Liu J, Wang X, Asahara T, Sykes M, Yang YG, Ohdan H. Role for CD47-SIRPalpha signaling in xenograft rejection by macrophages. Proc Natl Acad Sci USA. 2007; 104:5062-5066. [PubMed: 17360380]

89. Hoek RM, Ruuls SR, Murphy CA, Wright GJ, Goddard R, Zurawski SM, Blom B, Homola ME, Streit WJ, Brown MH, Barclay AN, Sedgwick JD. Down-regulation of the macrophage lineage through interaction with OX2 (CD200). Science. 2000; 290:1768-1771. [PubMed: 11099416]

90. Latour S, Tanaka H, Demeure C, Mateo V, Rubio M, Brown EJ, Maliszewski C, Lindberg FP, Oldenborg A, Ullrich A, Delespesse G, Sarfati M. Bidirectional negative regulation of human T and dendritic cells by CD47 and its cognate receptor signal-regulator protein-alpha: downregulation of IL-12 responsiveness and inhibition of dendritic cell activation. J Immunol. 2001; 167:2547-2554. [PubMed: 11509594]

91. Seiffert M, Brossart P, Cant C, Cella M, Colonna M, Brugger W, Kanz L, Ullrich A, Buhring HJ. Signal-regulatory protein alpha (SIRPalpha) but not SIRPbeta is involved in T-cell activation, binds to CD47 with high affinity, and is expressed on immature CD34(+)CD38(-) hematopoietic cells. Blood. 2001; 97:2741-2749. [PubMed: 11313266]

92. Hagnerud S, Manna PP, Cella M, Stenberg A, Frazier WA, Colonna M, Oldenborg PA. Deficit of CD47 results in a defect of marginal zone dendritic cells, blunted immune response to particulate antigen and impairment of skin dendritic cell migration. J Immunol. 2006; 176:5772-5778. [PubMed: 16670282]

93. Tomizawa T, Kaneko Y, Saito Y, Ohnishi H, Okajo J, Okuzawa C, Ishikawa-Sekigami T, Murata Y, Okazawa H, Okamoto K, Nojima Y, Matozaki T. Resistance to experimental autoimmune encephalomyelitis and impaired T cell priming by dendritic cells in Src homology 2 domaincontaining protein tyrosine phosphatase substrate-1 mutant mice. J Immunol. 2007; 179:869-877. [PubMed: 17617577]

94. Matsue H. CD 200-mediated regulation of skin immunity. J Invest Dermatol. 2005; 125:x-xi. [PubMed: 16354172]

95. Snelgrove RJ, Goulding J, Didierlaurent AM, Lyonga D, Vekaria S, Edwards L, Gwyer E, Sedgwick JD, Barclay AN, Hussell T. A critical function for CD200 in lung immune homeostasis and the severity of influenza infection. Nat Immunol. 2008; 9:1074-1083. [PubMed: 18660812]

96. Mukhopadhyay S, Pluddemann A, Hoe JC, Williams KJ, Varin A, Makepeace K, Aknin ML, Bowdish DM, Smale ST, Barclay AN, Gordon S. Immune inhibitory ligand CD200 induction by TLRs and NLRs limits macrophage activation to protect the host from meningococcal septicemia. Cell Host Microbe. 2010; 8:236-247. [PubMed: 20833375]

97. Gorczynski RM, Cattral MS, Chen Z, Hu J, Lei J, Min WP, Yu G, Ni J. An immunoadhesin incorporating the molecule OX-2 is a potent immunosuppressant that prolongs allo- and xenograft survival. J Immunol. 1999; 163:1654-1660. [PubMed: 10415071]

98. Boudakov I, Liu J, Fan N, Gulay P, Wong K, Gorczynski RM. Mice lacking CD200R1 show absence of suppression of lipopolysaccharide-induced tumor necrosis factor-alpha and mixed leukocyte culture responses by CD200. Transplantation. 2007; 84:251-257. [PubMed: 17667818]

99. Gorczynski RM, Chen Z, He W, Khatri I, Sun Y, Yu K, Boudakov I. Expression of a CD200 transgene is necessary for induction but not maintenance of tolerance to cardiac and skin allografts. J Immunol. 2009; 183:1560-1568. [PubMed: 19592654] 
100. Yu K, Chen Z, Wang S, Gorczynski R. Decreased alloreactivity using donor cells from mice expressing a CD200 transgene under control of a tetracycline-inducible promoter.

Transplantation. 2005; 80:394-401. [PubMed: 16082336]

101. Takenaka K, Prasolava TK, Wang JCY, Mortin-Toth SM, Khalouei S, Gan OI, Dick JE, Danska JS. Polymorphism in Sirpa modulates engraftment of human hematopoietic stem cells. Nat Immunol. 2007; 8:1313-1323. [PubMed: 17982459]

102. Blazar BR, Lindberg FP, Ingulli E, Panoskaltsis-Mortari A, Oldenborg PA, Iizuka K, Yokoyama WM, Taylor PA. CD47 (integrin-associated protein) engagement of dendritic cell and macrophage counterreceptors is required to prevent the clearance of donor lymphohematopoietic cells. J Exp Med. 2001; 194:541-549. [PubMed: 11514609]

103. Nakamura A, Kobayashi E, Takai T. Exacerbated graft-versus-host disease in Pirb-/- mice. Nat Immunol. 2004; 5:623-629. [PubMed: 15146181]

104. Chang CC, Ciubotariu R, Manavalan JS, Yuan J, Colovai AI, Piazza F, Lederman S, Colonna M, Cortesini R, Dalla-Favera R, Suciu-Foca N. Tolerization of dendritic cells by T(S) cells: the crucial role of inhibitory receptors ILT3 and ILT4. Nat Immunol. 2002; 3:237-243. [PubMed: 11875462]

105. Matzinger P. Tolerance, danger, and the extended family. Annu Rev Immunol. 1994; 12:9911045. [PubMed: 8011301]

106. Kono H, Rock KL. How dying cells alert the immune system to danger. Nat Rev Immunol. 2008; 8:279-289. [PubMed: 18340345]

107. Kaczorowski DJ, Tsung A, Billiar TR. Innate immune mechanisms in ischemia/reperfusion. Front Biosci (Elite Ed). 2009; 1:91-98. [PubMed: 19482628]

108. Martinon F, Petrilli V, Mayor A, Tardivel A, Tschopp J. Gout-associated uric acid crystals activate the NALP3 inflammasome. Nature. 2006; 440:237-241. [PubMed: 16407889]

109. Chen CJ, Kono H, Golenbock D, Reed G, Akira S, Rock KL. Identification of a key pathway required for the sterile inflammatory response triggered by dying cells. Nat Med. 2007; 13:851856. [PubMed: 17572686]

110. Shi Y, Evans JE, Rock KL. Molecular identification of a danger signal that alerts the immune system to dying cells. Nature. 2003; 425:516-521. [PubMed: 14520412]

111. Shi Y, Galusha SA, Rock KL. Cutting edge: elimination of an endogenous adjuvant reduces the activation of CD8 T lymphocytes to transplanted cells and in an autoimmune diabetes model. J Immunol. 2006; 176:3905-3908. [PubMed: 16547223]

112. Hu DE, Moore AM, Thomsen LL, Brindle KM. Uric acid promotes tumor immune rejection. Cancer Res. 2004; 64:5059-5062. [PubMed: 15289304]

113. Di Virgilio F, Boeynaems JM, Robson SC. Extracellular nucleotides as negative modulators of immunity. Curr Opin Pharmacol. 2009; 9:507-513. [PubMed: 19628431]

114. Sitkovsky MV, Lukashev D, Apasov S, Kojima H, Koshiba M, Caldwell C, Ohta A, Thiel M. Physiological control of immune response and inflammatory tissue damage by hypoxia-inducible factors and adenosine A2A receptors. Annu Rev Immunol. 2004; 22:657-682. [PubMed: 15032592]

115. Wilhelm K, Ganesan J, Muller T, Durr C, Grimm M, Beilhack A, Krempl CD, Sorichter S, Gerlach UV, Juttner E, Zerweck A, Gartner F, Pellegatti P, Di Virgilio F, Ferrari D, Kambham N, Fisch P, Finke J, Idzko M, Zeiser R. Graft-versus-host disease is enhanced by extracellular ATP activating P2X7R. Nat Med. 16:1434-1438. [PubMed: 21102458]

116. Robson SC, Wu Y, Sun X, Knosalla C, Dwyer K, Enjyoji K. Ectonucleotidases of CD39 family modulate vascular inflammation and thrombosis in transplantation. Semin Thromb Hemost. 2005; 31:217-233. [PubMed: 15852225]

117. Crikis S, Lu B, Murray-Segal LM, Selan C, Robson SC, D'Apice AJ, Nandurkar HH, Cowan PJ, Dwyer KM. Transgenic overexpression of CD39 protects against renal ischemia-reperfusion and transplant vascular injury. Am J Transplant. 2010; 10:2586-2595. [PubMed: 20840479]

118. Rubic T, Lametschwandtner G, Jost S, Hinteregger S, Kund J, Carballido-Perrig N, Schwarzler C, Junt T, Voshol H, Meingassner JG, Mao X, Werner G, Rot A, Carballido JM. Triggering the succinate receptor GPR91 on dendritic cells enhances immunity. Nat Immunol. 2008; 9:12611269. [PubMed: 18820681] 
119. Tsung A, Sahai R, Tanaka H, Nakao A, Fink MP, Lotze MT, Yang H, Li J, Tracey KJ, Geller DA, Billiar TR. The nuclear factor HMGB1 mediates hepatic injury after murine liver ischemiareperfusion. J Exp Med. 2005; 201:1135-1143. [PubMed: 15795240]

120. Moser B, Szabolcs MJ, Ankersmit HJ, Lu Y, Qu W, Weinberg A, Herold KC, Schmidt AM. Blockade of RAGE suppresses alloimmune reactions in vitro and delays allograft rejection in murine heart transplantation. Am J Transplant. 2007; 7:293-302. [PubMed: 17241110]

121. LaRosa DF, Rahman AH, Turka LA. The innate immune system in allograft rejection and tolerance. J Immunol. 2007; 178:7503-7509. [PubMed: 17548582]

122. Zhang Q, Raoof M, Chen Y, Sumi Y, Sursal T, Junger W, Brohi K, Itagaki K, Hauser CJ. Circulating mitochondrial DAMPs cause inflammatory responses to injury. Nature. 2010; 464:104-107. [PubMed: 20203610]

123. West PA, Shadel GS, Ghosh S. Mitochondria in innate immune responses. Nature Reviews Immunology. 2011; 11:389-402.

124. Liang Y, Christopher K, Finn PW, Colson YL, Perkins DL. Graft produced interleukin-6 functions as a danger signal and promotes rejection after transplantation. Transplantation. 2007; 84:771-777. [PubMed: 17893611]

125. Chalasani G, Dai Z, Konieczny BT, Baddoura FK, Lakkis FG. Recall and propagation of allospecific memory T cells independent of secondary lymphoid organs. Proc Natl Acad Sci USA. 2002; 99:6175-6180. [PubMed: 11983909]

126. Anderson C, Carroll J, Gallucci S, Ridge J, Cheever A, Matzinger P. Testing time-, ignorance-, and danger-based models of tolerance. J Immunol. 2001; 166:3663-3671. [PubMed: 11238605]

127. Jones JD, Dangl JL. The plant immune system. Nature. 2006; 444:323-329. [PubMed: 17108957]

128. Martinon F, Mayor A, Tschopp J. The inflammasomes: guardians of the body. Annu Rev Immunol. 2009; 27:229-265. [PubMed: 19302040]

129. Morita K, Miura M, Paolone DR, Engeman TM, Kapoor A, Remick DG, Fairchild RL. Early chemokine cascades in murine cardiac grafts regulate $\mathrm{T}$ cell recruitment and progression of acute allograft rejection. J Immunol. 2001; 167:2979-2984. [PubMed: 11509648]

130. Kreisel D, Sugimoto S, Tietjens J, Zhu J, Yamamoto S, Krupnick AS, Carmody RJ, Gelman AE. $\mathrm{Bcl} 3$ prevents acute inflammatory lung injury in mice by restraining emergency granulopoiesis. $\mathrm{J}$ Clin Invest. 2011; 121:265-276. [PubMed: 21157041]

131. El-Sawy T, Belperio J, Strieter R, Fairchild RL. Long term allograft survival following attenuation of the early inflammatory response plus short term co-stimulatory molecule blockade. Am J Transplantation. 2004; 4:579A.

132. El-Sawy T, Belperio JA, Strieter RM, Remick DG, Fairchild RL. Inhibition of polymorphonuclear leukocyte-mediated graft damage synergizes with short-term costimulatory blockade to prevent cardiac allograft rejection. Circulation. 2005; 112:320-331. [PubMed: 15998678]

133. Muller I, Munder M, Kropf P, Hansch GM. Polymorphonuclear neutrophils and T lymphocytes: strange bedfellows or brothers in arms? Trends Immunol. 2009; 30:522-530. [PubMed: 19775938]

134. van Gisbergen KP, Sanchez-Hernandez M, Geijtenbeek TB, van Kooyk Y. Neutrophils mediate immune modulation of dendritic cells through glycosylation-dependent interactions between Mac-1 and DC-SIGN. J Exp Med. 2005; 201:1281-1292. [PubMed: 15837813]

135. Potter NS, Harding CV. Neutrophils process exogenous bacteria via an alternate class I MHC processing pathway for presentation of peptides to T lymphocytes. J Immunol. 2001; 167:25382546. [PubMed: 11509593]

136. Auffray C, Fogg D, Garfa M, Elain G, Join-Lambert O, Kayal S, Sarnacki S, Cumano A, Lauvau G, Geissmann F. Monitoring of blood vessels and tissues by a population of monocytes with patrolling behavior. Science. 2007; 317:666-670. [PubMed: 17673663]

137. Swirski FK, Nahrendorf M, Etzrodt M, Wildgruber M, Cortez-Retamozo V, Panizzi P, Figueiredo JL, Kohler RH, Chudnovskiy A, Waterman P, Aikawa E, Mempel TR, Libby P, Weissleder R, Pittet MJ. Identification of splenic reservoir monocytes and their deployment to inflammatory sites. Science. 2009; 325:612-616. [PubMed: 19644120] 
138. Geissmann F, Manz MG, Jung S, Sieweke MH, Merad M, Ley K. Development of monocytes, macrophages, and dendritic cells. Science. 2010; 327:656-661. [PubMed: 20133564]

139. Dominguez PM, Ardavin C. Differentiation and function of mouse monocyte-derived dendritic cells in steady state and inflammation. Immunol Rev. 2010; 234:90-104. [PubMed: 20193014]

140. Kreisel D, Nava RG, Li W, Zinselmeyer BH, Wang B, Lai J, Pless R, Gelman AE, Krupnick AS, Miller MJ. In vivo two-photon imaging reveals monocyte-dependent neutrophil extravasation during pulmonary inflammation. Proc Natl Acad Sci U S A. 2011; 107:18073-18078. [PubMed: 20923880]

141. Gelman AE, Okazaki M, Sugimoto S, Li W, Kornfeld CG, Lai J, Richardson SB, Kreisel FH, Huang HJ, Tietjens JR, Zinselmeyer BH, Patterson GA, Miller MJ, Krupnick AS, Kreisel D. CCR2 regulates monocyte recruitment as well as CD4 T1 allorecognition after lung transplantation. Am J Transplant. 2010; 10:1189-1199. [PubMed: 20420631]

142. Zecher D, van Rooijen N, Rothstein D, Shlomchik W, Lakkis F. An Innate Response to Allogeneic Nonself Mediated by Monocytes. J Immunol. 2009

143. Fox A, Mountford J, Braakhuis A, Harrison LC. Innate and adaptive immune responses to nonvascular xenografts: evidence that macrophages are direct effectors of xenograft rejection. $\mathrm{J}$ Immunol. 2001; 166:2133-2140. [PubMed: 11160265]

144. Kirk A, Hale D, Mannon R, Kleiner D, Hoffmann S, Kampen R, Cendales L, Tadaki D, Harlan D, Swanson S. Results from a human renal allograft tolerance trial evaluating the humanized CD52specific monoclonal antibody alemtuzumab (CAMPATH-1H). Transplantation. 2003; 76:120129. [PubMed: 12865797]

145. Xu H, Dhanireddy KK, Kirk AD. Human monocytes as intermediaries between allogeneic endothelial cells and allospecific T cells: a role for direct scavenger receptor-mediated endothelial membrane uptake in the initiation of alloimmunity. J Immunol. 2006; 176:750-761. [PubMed: 16393958]

146. Serafini P, Borrello I, Bronte V. Myeloid suppressor cells in cancer: recruitment, phenotype, properties, and mechanisms of immune suppression. Semin Cancer Biol. 2006; 16:53-65. [PubMed: 16168663]

147. Garcia MR, Ledgerwood L, Yang Y, Xu J, Lal G, Burrell B, Ma G, Hashimoto D, Li Y, Boros P, Grisotto M, van Rooijen N, Matesanz R, Tacke F, Ginhoux F, Ding Y, Chen SH, Randolph G, Merad M, Bromberg JS, Ochando JC. Monocytic suppressive cells mediate cardiovascular transplantation tolerance in mice. J Clin Invest. 2010; 120:2486-2496. [PubMed: 20551515]

148. Marigo I, Bosio E, Solito S, Mesa C, Fernandez A, Dolcetti L, Ugel S, Sonda N, Bicciato S, Falisi E, Calabrese F, Basso G, Zanovello P, Cozzi E, Mandruzzato S, Bronte V. Tumor-induced tolerance and immune suppression depend on the $\mathrm{C} / \mathrm{EBPb}$ ta transcription factor. Immunity. 2010; 32:790-802. [PubMed: 20605485]

149. Wu T, Bond G, Martin D, Nalesnik MA, Demetris AJ, Abu-Elmagd K. Histopathologic characteristics of human intestine allograft acute rejection in patients pretreated with thymoglobulin or alemtuzumab. Am J Gastroenterol. 2006; 101:1617-1624. [PubMed: 16863569]

150. Braun MY, Desalle F, Le Moine A, Pretolani M, Matthys P, Kiss R, Goldman M. IL-5 and eosinophils mediate the rejection of fully histoincompatible vascularized cardiac allografts: regulatory role of alloreactive CD8(+) T lymphocytes and IFN-gamma. Eur J Immunol. 2000; 30:1290-1296. [PubMed: 10820374]

151. Goldman M, Le Moine A, Braun M, Flamand V, Abramowicz D. A role for eosinophils in transplant rejection. Trends Immunol. 2001; 22:247-251. [PubMed: 11323281]

152. Sayed BA, Christy A, Quirion MR, Brown MA. The master switch: the role of mast cells in autoimmunity and tolerance. Annu Rev Immunol. 2008; 26:705-739. [PubMed: 18370925]

153. Secor VH, Secor WE, Gutekunst CA, Brown MA. Mast cells are essential for early onset and severe disease in a murine model of multiple sclerosis. J Exp Med. 2000; 191:813-822. [PubMed: 10704463]

154. Lu LF, Lind EF, Gondek DC, Bennett KA, Gleeson MW, Pino-Lagos K, Scott ZA, Coyle AJ, Reed JL, Van Snick J, Strom TB, Zheng XX, Noelle RJ. Mast cells are essential intermediaries in regulatory T-cell tolerance. Nature. 2006; 442:997-1002. [PubMed: 16921386] 
155. Neill DR, Wong SH, Bellosi A, Flynn RJ, Daly M, Langford TK, Bucks C, Kane CM, Fallon PG, Pannell R, Jolin HE, McKenzie AN. Nuocytes represent a new innate effector leukocyte that mediates type-2 immunity. Nature. 464:1367-1370. [PubMed: 20200518]

156. Sokol CL, Chu NQ, Yu S, Nish SA, Laufer TM, Medzhitov R. Basophils function as antigenpresenting cells for an allergen-induced T helper type 2 response. Nat Immunol. 2009; 10:713720. [PubMed: 19465907]

157. Sokol CL, Barton GM, Farr AG, Medzhitov R. A mechanism for the initiation of allergeninduced T helper type 2 responses. Nat Immunol. 2008; 9:310-318. [PubMed: 18300366]

158. Finkelman FD. Basophils as Th2-inducing APCs: the dog can sign but is it a diva? 2009; 87:568570.

159. Buss L. Somatic cell parasitism and the evolution of somatic tissue compatibility. Proc Natl Acad Sci (USA). 1982; 79:5337-5341. [PubMed: 6957867]

160. Laird D, De Tomaso A, Weissman I. Stem cells are unit of natural selection in a colonial ascidian. Cell. 2005; 123:1351-1360. [PubMed: 16377573]

161. Poudyal M, Rosa S, Powell AE, Moreno M, Dellaporta SL, Buss LW, Lakkis FG. Embryonic chimerism does not induce tolerance in an invertebrate model organism. Proc Natl Acad Sci U S A. 2007; 104:4559-4564. [PubMed: 17360563]

162. Pearse AM, Swift K. Allograft theory: transmission of devil facial-tumour disease. Nature. 2006; 439:549. [PubMed: 16452970]

163. Murgia C, Pritchard J, Kim S, Fassati A, Weiss R. Clonal origin and evolution of a transmissible cancer. Cell. 2006; 126:477-487. [PubMed: 16901782]

164. Burnet FM. "Self-recognition" in colonial marine forms and flowering plants in relation to the evolution of immunity. Nature. 1971; 232:230-235. [PubMed: 4937075]

165. De Tomaso A, Nyholm S, Palmeri K, Ishizuka K, Ludington W, Mitchel K, Weissman I. Isolation and characterization of a protochordate histocompatibility locus. Nature. 2005; 438:454-459. [PubMed: 16306984]

166. Nicotra ML, Powell AE, Rosengarten RD, Moreno M, Grimwood J, Lakkis FG, Dellaporta SL, Buss LW. A Hypervariable Invertebrate Allodeterminant. Curr Biol. 2009

167. Rosengarten RD, Nicotra ML. Model systems of invertebrate allorecognition. Curr Biol. 2011; 21:R82-92. [PubMed: 21256442] 


\section{Highlights}

1. The innate immune system is a non-self recognition system responsible for triggering adaptive immunity by activating antigen presenting cells.

2. Innate mechanisms critical for microbial recognition contribute to but are neither necessary nor sufficient for alloimmunity or rejection.

3. Cell damage or death associated with the transplantation procedure releases a large variety of 'danger' molecules that potentiate rejection.

4. Innate immune cells, such as monocytes, can distinguish between self and allogeneic non-self. The molecular mechanisms are not known.

5. Investigating the role of the innate immune system in memory $\mathrm{T}$ cell recall is particularly relevant to alloimmunity and rejection. 